\title{
Reining in assisted reproduction
}

Fears about the safety of reproductive technologies should be kept in perspective, but more research is needed to assess the risks. In the meantime, its practitioners should learn the virtue of caution.

ertility specialists derive enormous satisfaction from their work. Whereas many doctors are confronted daily with patients who are struggling against death, the fertility expert's stock-intrade is the creation of life. It must be uplifting to arrive at work each morning and glance up at a wall filled with smiling family portraits that are the direct result of your professional endeavours.

But this emotional reward, along with the commercial pressures that bear on private reproductive clinics, means that caution is not always the watchword. Many clinics tout for business by quoting their success rate, so they are eager to adopt techniques that boost the chance of a successful pregnancy. At the same time, a desire to help more couples experience the joys of parenthood has led reproductive specialists to adopt more aggressive techniques to treat infertility. Intracytoplasmic sperm injection (ICSI), for instance, in which a sperm cell is injected directly into the egg, is now a routine procedure.

Some researchers are now starting to question the safety of ICSI and other techniques, claiming that they are linked with increased rates of birth defects and rare 'genetic imprinting' disorders (see page 656). This sounds alarming, but it's important to keep the fears in perspective. So far, the few studies done are mostly based on small sample sizes, and in some cases the findings are contested. Other studies on children conceived by assisted reproduction have found no evidence of any problems, and some developmental biologists see no reason to suppose that such techniques should pose a significant risk.

But there are good reasons to urge caution. We know from studies of livestock, where the manipulation of eggs and embryos is often more severe than in human fertility clinics, that such interventions may be associated with a syndrome in which fetuses grow too large, and may die at around the time of birth. Disturbingly, there seem to be parallels between this condition and the imprinting disorders now being linked tentatively to assisted human conception.

The tendency of human fertility specialists to push the boundaries ever outwards is a further cause for concern. Consider, for example, the sorry tale of cytoplasmic transfer, pioneered by Jacques Cohen of the Institute for Reproductive Medicine and Science of Saint Barnabas in Livingston, New Jersey. By injecting their eggs with cytoplasm from eggs donated by younger women, Cohen enabled some infertile women to have a child. But the technique also seems to heighten the risk of a chromosomal abnormality.

Few would argue that such adventures are desirable, but how can they be curbed? Requiring all new assisted-reproduction techniques to undergo full clinical trials would probably bring progress to an end. But Nature has argued previously that there is much to commend the British model, under which a statutory authority regulates fertility clinics and researchers (see Nature 420, 1; 2002). In many countries, clinics in the private sector are given too free a rein.

There is also a need for more research to assess the risks posed by assisted reproduction. This will require further epidemiological follow-up and studies to determine whether the embryos created bear any cellular or molecular abnormalities. The current US administration, unfortunately, is unlikely to provide federal dollars for research on human embryos. For the sake of future generations of assisted-reproduction children, funding bodies in more permissive countries should rise to this important challenge.

\section{Anything you can do...}

Spy scandals notwithstanding, the party goes on at the two US nuclear-weapons design labs - and so does the backbiting.

$\mathrm{T}$ he Lawrence Livermore National Laboratory grew out of a lab established in 1952 by a group of dedicated individuals who believed they could do better than Los Alamos, and build a hydrogen bomb. Some of them also believed that Los Alamos was run by communist sympathizers, and testified in Congress to that effect.

The two establishments have had a less-than-cordial relationship ever since. Their rivalry retains a sharp edge: only last year, Livermore staff sabotaged an effort to foist on them a director who had spent most of his career at Los Alamos (see Nature 417, 577; 2002). The rivalry has suited successive US governments just fine, but the latest arena of competition may be less pleasing to Washington. Almost five years after Los Alamos descended into the Wen Ho Lee spy scandal, Livermore has now embarked on a spectacular riposte (see page 651).

Los Alamos may have been content to oversee the bungled investigation of a middle-aged Taiwanese mechanical engineer, struggling to figure out which thermodynamics meetings he had attended in Asia. Livermore, as always, seems to have been up to something more exotic.

According to court documents, the head of security at Livermore (before he resigned last week) enjoyed an on-off relationship over many years with a Los Angeles socialite and Republican fundraiser,
Katrina Leung, who worked for the FBI but is now in prison pending trial on charges that she was also operating as a double agent for Beijing. The FBI's nightmare is that her alleged operation may have enabled China to keep an eye on all of the agency's spying investigations - including those involving leaks from Livermore, Los Alamos and elsewhere - over two decades.

There's no sign that any scientists from Livermore were invited to the splendid garden parties that Leung liked to throw in one of Los Angeles' smartest neighbourhoods. It's not clear that she was particularly interested in the technicalities of nuclear weaponry: she was more of a person person, by all accounts.

Nonetheless, the queue of postdocs keen to further their careers at both Livermore and Los Alamos remains impressive. It isn't just the glamour that draws them, it is the money that Congress continues to pump into each establishment. During the Wen Ho Lee scandal, there was talk that this largesse might dry up; instead, it has multiplied. If, as seems increasingly certain, Livermore's most valuable innovations in the miniaturization of thermonuclear warheads were passed straight to Beijing in the 1980s, that's all the more reason, Congress seems to think, to innovate some more. 